\title{
Reproductive response of Calanus helgolandicus. I. Abnormal embryonic and naupliar development
}

\author{
S. A. Poulet ${ }^{1, *}$, M. Laabir ${ }^{1}$, A. Ianora ${ }^{2}$, A. Miralto ${ }^{2}$ \\ ${ }^{1}$ Station Biologique de Roscoff, CNRS el Université Paris VI, F-28682 Roscoff, France \\ ${ }^{2}$ Stazione Zoologica Anton Dohrn, Villa Comunale, I-80121 Naples, Italy
}

\begin{abstract}
Abnormal embryonic development is described for the copepod Calanus helgolandicus Anomalies followed ingestion of diatoms by females which led to erroneous synchronization between nuclear division and cytokinesis, with malformation of the cellular membrane between daughter cells during mitosis. Similar types of cellular anomalies and morphological deformities, reported for the first time in the embryonic and naupliar stages of $C$. helgolandicus, were observed both in the laboratory and in situ. The ecological importance of this process as a factor controlling mortality and recruitment of copepods in the ocean is discussed
\end{abstract}

KEY WORDS: Calanus helgolandicus - Embryonic development - Anatomical deformities

\section{INTRODUCTION}

In temperate waters, copepod standing stocks undergo large seasonal variations. Peaks of copepod biomass generally follow the spring phytoplankton bloom, while significant mortality occurs during summer and fall (Kiørboe \& Nielsen 1994), even though secondary production is still high during these periods. The seasonal cycle of copepod population is thus regulated both by productivity and mortality, the causes of which are still incompletely understood.

Recent studies have suggested that part of the decline in copepod biomass which occurs during the year can be due to low hatching success (Ianora et al. 1992, Ianora \& Poulet 1993, Jonasdottir 1994, Ianora et al. 1995) in relation to the concentration and type of diatoms available and consumed by adult females (Ianora \& Poulet 1993, Poulet et al. 1994, Laabir et al. 1995a). This type of mortality affects embryonic development and is a component of what we define as 'natural mortality'. Over the year, it can vary between 20 and $100 \%$ of the daily egg production estimated in the field (Ianora et al. 1992, 1995, Laabir et al. 1995a). Survivorship and development of naupliar stages is

·E-mail: poulet@sb-roscoff.fr also affected by predation, the type of food and the timing of initial first feeding (Landry 1975, Uye 1982, Lopez et al. 1993). Combined mortality due to predation (Uye 1982, Liang et al. 1994), inhibition by diatoms (Poulet et al. 1994) and loss in the mud of dormant eggs (Kasahara et al. 1975) may account for the resulting 10 to $20 \%$ survivorship of late nauplii and copepodites. Measurement of viability during the early life stages is thus essential for estimation of recruitment in copepods (Poulet et al. 1995). It follows that preliminary identification of morphological anomalies is necessary for in situ measurement and prediction of natural mortality of eggs.

Descriptions of normal eggs, embryos and nauplii have been published for Calanus finmarchicus (see Marshall \& Orr 1972). However, morphological malformations in these early development stages have never been reported before. In adult female Clausocalanus sp., 1 to $8 \%$ deformity of the fifth limbs was described (Williams \& Wallace 1975 and review therein), but the causes were unknown. This type of malformation may lower the reproduction capability of females. It seems possible that other anomalies affecting the embryonic phase, and their consequences on the morphological deformities of naupliar stages, might interfere with the process of development, hatching and swimming, or simply lead to a reduction in fitness 
Thus, they may have serious consequences on the survival of individuals and on recruitment of any population with a high incidence of anomalies.

In this paper several methods were used to determine and describe cellular anomalies, morphological deformities and biometrics observed in Calanus helgolandicus eggs in relation to the viability of embryos and naupliar stages. Our objective was to determine the causes of mortality.

\section{MATERIALS AND METHODS}

Calanus helgolandicus eggs are transparent, allowing direct microscopic observation of each embryonic developmental stage up to hatching. Eggs studied during this work were spawned by females, collected in the western English Channel offshore of Roscoff (France) in various seasons of the years 1992, 1993 and 1994. Batches of $n \geq 20$ eggs each were incubated in dishes containing 0.5 to $1 \mathrm{ml}$ filtered sea water $(0.22 \mu \mathrm{m})$, at room temperature $\left(12\right.$ to $\left.16 \pm 0.5^{\circ} \mathrm{C}\right)$, corresponding to ambient field temperatures at the time of capture of the adults. Duration of incubations to reach hatching of naupliar stages N1 and N2 were 24 to $92 \mathrm{~h}$, depending on the temperature.

Normal eggs and healthy nauplii were produced by females incubated $24 \mathrm{~h}$ in unfiltered offshore sea water samples, collected at the same time, following the method described in Laabir et al. (1995b). Abnormal embryos were obtained following 3 different methods. First, abnormal eggs leading to both dead embryos and deformed nauplii N1 were produced by 5 to 12 females pooled in $200 \mathrm{ml}$ filtered sea water and fed dense diatom cultures Phaeodactylum tricomutum, at concentrations in dishes varying between 1 and $25 \times$ $10^{5}$ cells $\mathrm{ml}^{-1}$. Second, the abnormal eggs were artificially induced by incubating freshly spawned normal eggs for 1 to $4 \mathrm{~h}$ in extracts of dense diatom cultures, similar to the concentrations fed to females. Extracts were prepared according to the method described in Poulet et al. (1994). Between 10 and $20 \%$ of these eggs were able to hatch, giving rise to abnormal nauplii. Third, abnormal eggs were spawned in the laboratory by wild females collected during spring-summer diatom blooms occurring in coastal waters off Roscoff. Most of these eggs did not develop normally, and only a few deformed nauplii were produced (see Laabir et al. 1995a). Observation of embryonic and naupliar anomalies were achieved and compared with normal clutches of eggs, spawned by wild females. All incubations were made at room temperature $\left(16 \pm 0.5^{\circ} \mathrm{C}\right)$.

Embryos were observed in bright field Nomarsky and fluorescent light. Batches of 20 to 30 eggs were initially dyed for 10 min with $100 \mu$ l Hoechst 33342 (specific for
DNA; Sigma) solution (1 $\mathrm{mg} \mathrm{m}^{-1}$ of distilled water) in $400 \mu$ filtered sea water. Normal and abnormal development phases were observed starting at the fusion of male and female pronuclei (see Marshall \& Orr 1972). The main cellular characteristics used to identify early anomalies were the shape of the cells and colour of the outer egg membrane, cleavage of the cell membrane, and dispersion of chromatin in the egg matrix. These observations were made for different developmental stages, from newly spawned eggs to stage N2 nauplii using an Olympus microscope, and photographs (Kodak film 400 ASA) were routinely taken.

Detection of cellular anomalies and comparison with normal structures were also made using transmission electron microscopy (TEM). To do this, wild females were sorted into a crystallizing dish, and eggs were collected as they were spawned by scanning the container bottoms every 5 to $10 \mathrm{~min}$. To obtain abnormal eggs, females were either fed ad libitum with dense diatom cultures or newly spawned eggs were placed in dense diatom extracts $\left(10^{5}\right.$ cells $\left.\mathrm{ml}^{-1}\right)$. Batches of 10 to 20 normal (controls) and abnormal eggs were sampled $10,20,30,40$ min and $3 \mathrm{~h}$ after spawning, and fixed for $24 \mathrm{~h}$ in a mixture of $2.5 \%$ gluteraldehyde and $1 \%$ formaldehyde buffered to pH 7.2 with $0.2 \mathrm{M}$ sodium cacodylate and $20 \%$ sea water (Arnaud et al. 1978). Samples were then rinsed for $2 \mathrm{~h}$ and post-fixed in $1 \%$ osmium tetroxide for $1 \mathrm{~h}$. After dehydration in an alcohol series, samples were embedded in epon and sectioned with an ultramicrotome. Sections were stained with uranyl acetate and lead citrate according to Reynolds (1963) and examined with a Philips 400 TEM.

In some species of fish, egg size was reported as a criterion to estimate and predict viability of embryos (Kjørsvik et al. 1990). A similar approach was applied to Calanus helgolandicus eggs, using an image analysis technique. Batches of 50 to 180 eggs each 3 to $5 \mathrm{~h}$ old were placed in dishes containing 2 to $3 \mathrm{ml}$ filtered sea water and were observed under an Olympus microscope equipped with a CCD black and white video camera linked to a PC computer, using the Biocom program package (Biocom 2000 Co., France). Images of eggs were digitised and 5 biometric parameters (i.e. small and large diameters, perimeter, equivalent spherical diameter, spherical index) as well as transparency were measured. Egg transparency was deduced from an algorithm produced automatically by the program. Hatching success was measured daily or weekly, and used as a routine criteria to determine egg viability and embryonic development. Subsamples of eggs from the same clutch, used to estimate field viability, were incubated in parallel at in situ temperatures to determine hatching success. This practice was necessary, since the temperature of the dish increased $\left(>20^{\circ} \mathrm{C}\right)$ during the analysis, inducing 


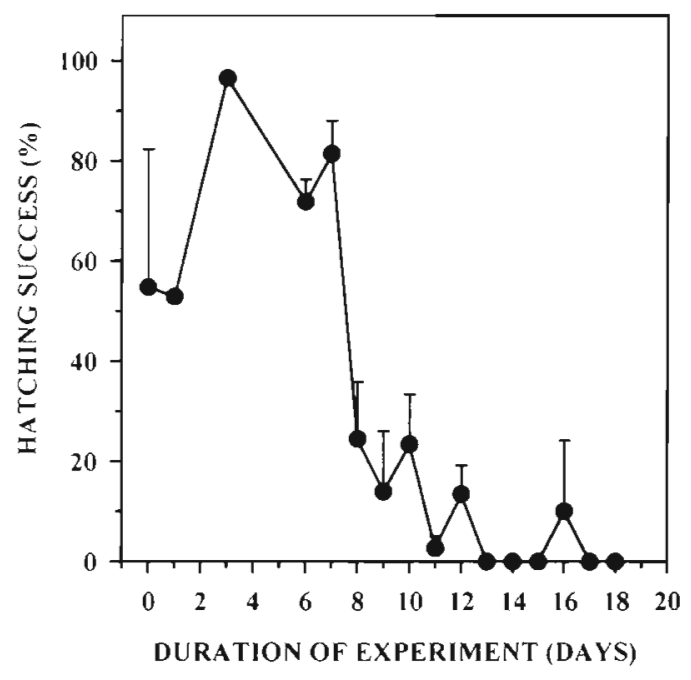

Fig. 1. Calanus helgolandicus. Variation of hatching success for females incubated $18 \mathrm{~d}$ with dense cultures of the diatom Phaeodactylum tricornutum ( 1 to $25 \times 10^{5}$ cells $\mathrm{ml}^{-1}$ ). Results are means $\pm \mathrm{SD}$ of triplicate samples $(\mathrm{n}=30$ to 60 eggs per sample). Controls correspond to field estimate of hatching rate before start of feeding experiments (i.e. time 0 )

premature death of most eggs placed under the microscope. Image analyses for a total of 600 eggs were conducted monthly from March to August 1993, allowing for a good coverage of the major natural and seasonal variations of embryonic mortality occurring in the coastal waters off Roscoff (see Laabir et al. 1995a).

\section{RESULTS}

A simple method to collect abnormal eggs and nauplii was to feed Calanus helgolandicus females with dense cultures of the diatom Phaeodactylum tricornutum. The results in Fig. 1 show that beyond the 8 th day of incubation, hatching success had decreased sharply compared to controls (i.e. initial hatching rate before feeding on diatoms). More than $80 \%$ of the resulting embryos were abnormal. Photographs of 6 specific developmental stages, corresponding to those which had the most visible microscopic structures, were made:

(1) egg stage: fusion of male and female pronuclei (1 blastomere: 1B, 5 min after spawning);

(2) first cleavage (2 blastomeres: $2 \mathrm{~B}, 30 \mathrm{~min}$ after spawning);

(3) 8-cell stage (8 blastomeres: 8B, 60 min after spawning);

(4) 32-cell stage (32 blastomeres: 32B, 3 h after spawning);

(5) larval stage before hatching (24 h old embryo);

(6) naupliar stages $N 1$ and $N 2$ (26 to $72 \mathrm{~h}$ after spawning).
Comparison was not possible beyond naupliar stage N1, since N2 nauplii were rarely obtained in the laboratory, and since those belonging to abnormal clutches generally died soon after hatching.

Various macroscopic descriptions of normal eggs, embryos and naupliar stages were reported earlier in Calanus finmarchicus (Marshall \& Orr 1972). In C. helgolandicus, similar developmental stages are briefly illustrated in Fig. 2, in bright field Nomarsky (Fig. 2A, C, E, G) and fluorescent light (Fig. 2B, D, F, H). During the egg and embryonic stages up to the segmentation cavity stage, all cells were similar in shape and size, and were symmetrically organized, showing a well developed cell membrane between daughter cells after the first cleavage. Each embryo also had a clear, transparent outer membrane. Absence of the fertilization membrane (Fig. 2A, E, G) did not seem to affect egg viability. This membrane (Fig. 2C) could be easily lost when eggs were pipetted. Male and female pronuclei, polar bodies, as well as nuclei in cells of older embryos, were spherical and symmetrically distributed in the egg matrix (Fig. 2B, D, F, H).

Similar observations of eggs and embryos, collected in abnormal clutches, were made in bright field Nomarsky (Fig. 3A, C, E, G) and fluorescent light (Fig. 3B, D, F, H). In the early egg phase, it was almost impossible to identify anomalies using such microscopic techniques (Fig. 3A, B), since abnormal eggs resembled normal ones (Fig. 2A, B). However, 2 criteria allowed for the identification of this category of eggs: they had a darker and more granular membrane (Fig. 3A) and they generally did not hatch. Embryonic anomalies were easily distinguished in older embryos. They were characterized by a darker colour, absence of a cell membrane, which was occasionally or partially formed, and by scattered, irregular, asymmetrical 'globules' corresponding to nuclei (Fig. 3A, C, E, G). In fluorescent light, the same basic anomalies were observed in all developmental stages. Smaller, condensed, irregular nuclei were randomly scattered in the egg matrix, or grouped together in proximity of the inner egg membrane (Fig. 3C-H). These cellular, structural anomalies reflected an erroneous timing between the synchronization of nuclear division and cell membrane formation during mitosis. Furthermore, the absence of a cell membrane between daughter cells (Fig. 3D, F, G) indicated that cytokinesis (i.e. cytoplasm cleavage and separation of daughter cells) was also modified. In most of these embryos, development was arrested at the morula or gastrula stages, and death occurred shortly after.

Photographs of the final stages of embryonic development prior to hatching, and of the first and second naupliar stages of Calanus helgolandicus are shown in Fig. 4 for normal and abnormal clutches. In the case of 

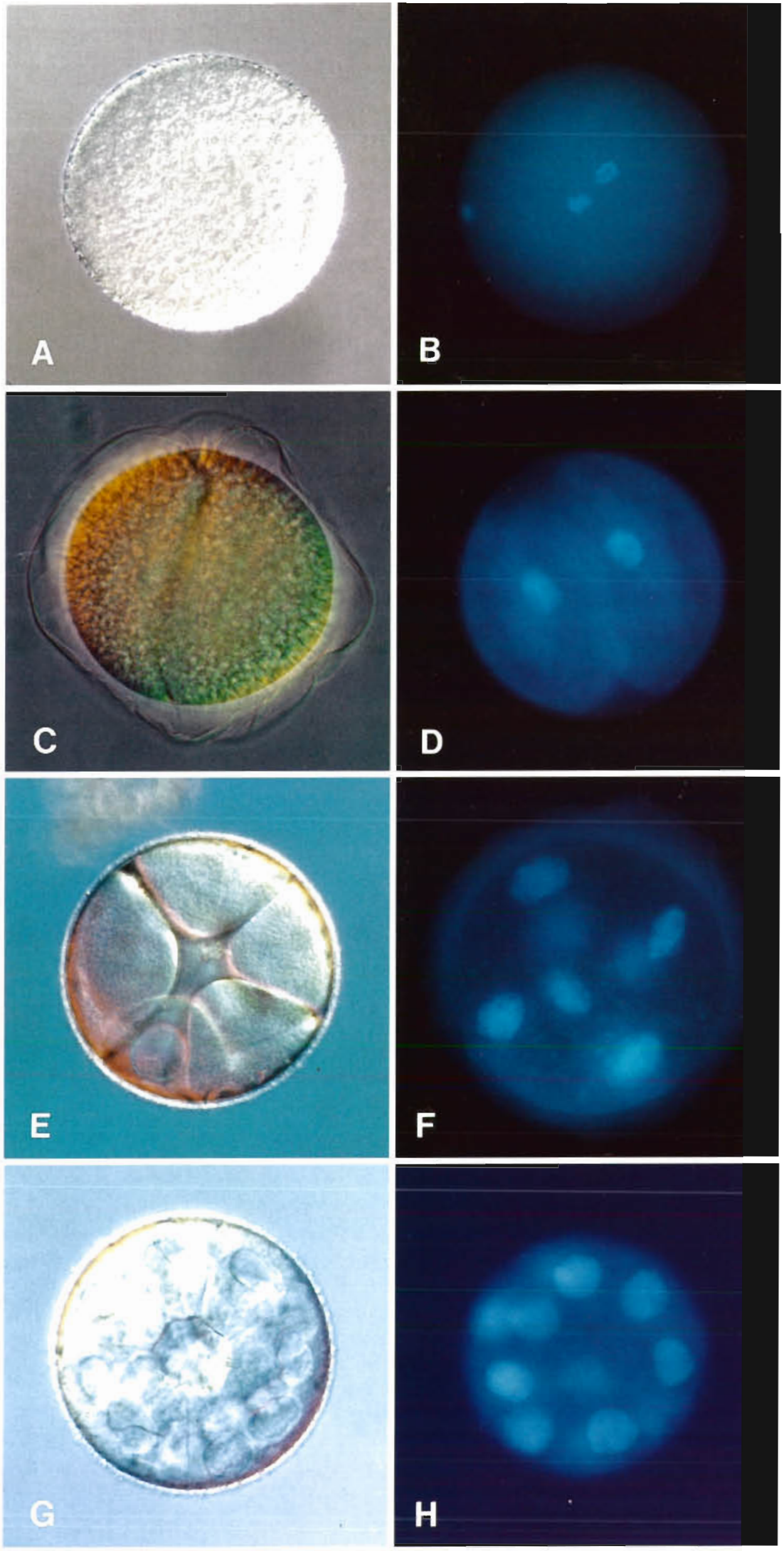

Fig. 2. Calanus helgolandicus. Light microscope photographs of normal eggs and embryos $(160$ to $175 \mu \mathrm{m}$ diameter) dyed with Hoechst 33342. Left $(A, C, E, G)$ in bright field Nomarsky; and right $(B, D, F, H)$ in fluorescent light. Newly spawned eggs (A, B: before fusion of male and female pronuclei). and older embryos (at 2B stage: $C, D ; 8 B$ stage: $E, F$; and morula stage: $G, H$ ) presented normal structures 

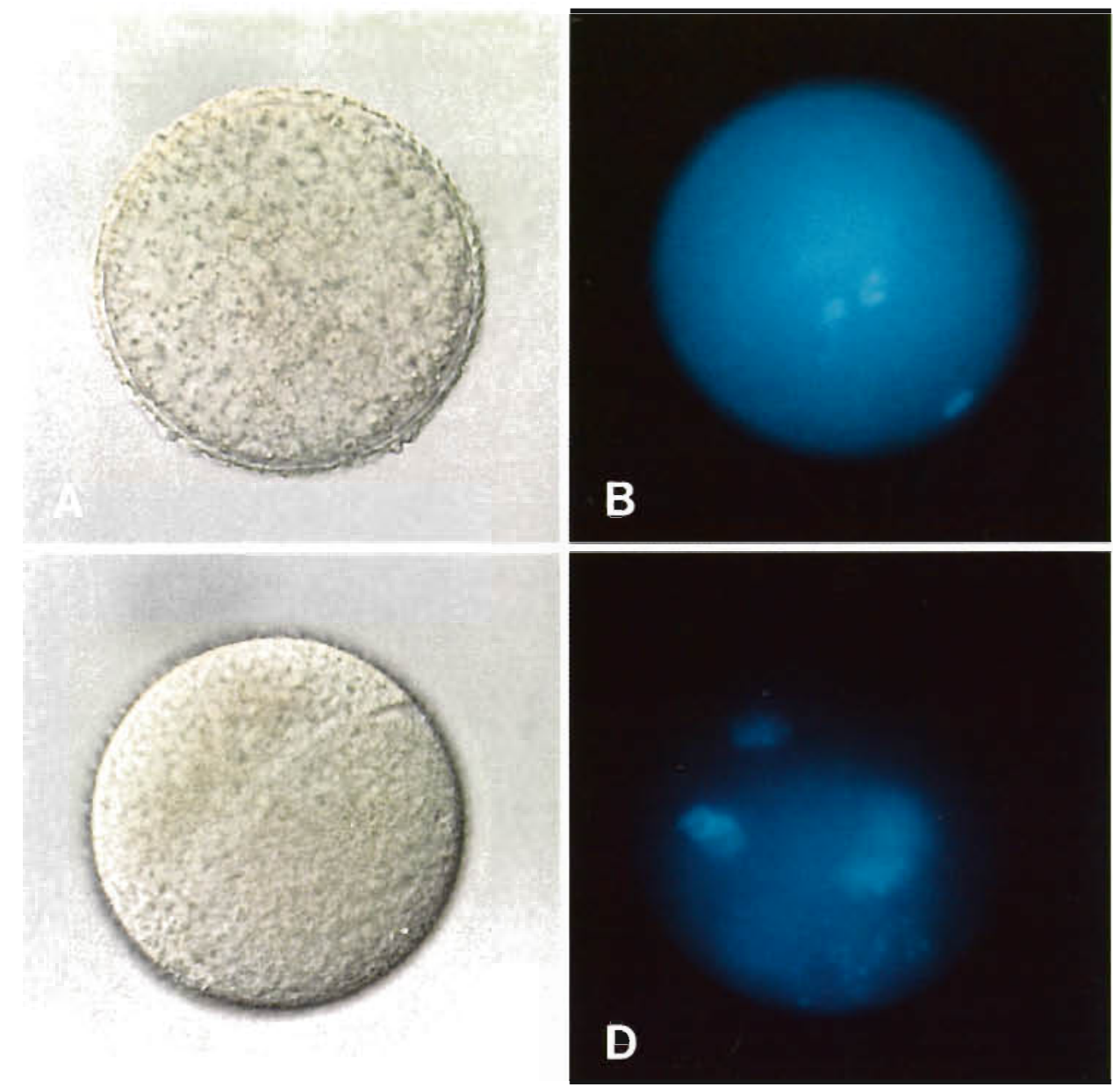

Fig. 3. Calanus helgolandiclis. Light microscope photographs of abnormal eggs and embryos (same conditions as in Fig. 2) Newly spawned eggs (A, B: before fusion of male and female pronucleil, and older embryos (at $2 \mathrm{~B}$ stage: $C, D ; 60$ min old embryo: $\mathrm{E}, \mathrm{F}$; and $3 \mathrm{~h}$ old embryo: $G, H)$ presented abnormal cellular structures. Images A, B \& E, F represent abnormal clutches produced by wild females feeding on naturally occurring diatoms Images C, D \& G, H represent clutches produced in the laboratory by females fed dense cultures of Phaeodactylum tricornutum (same conditions as in Fig. 1)
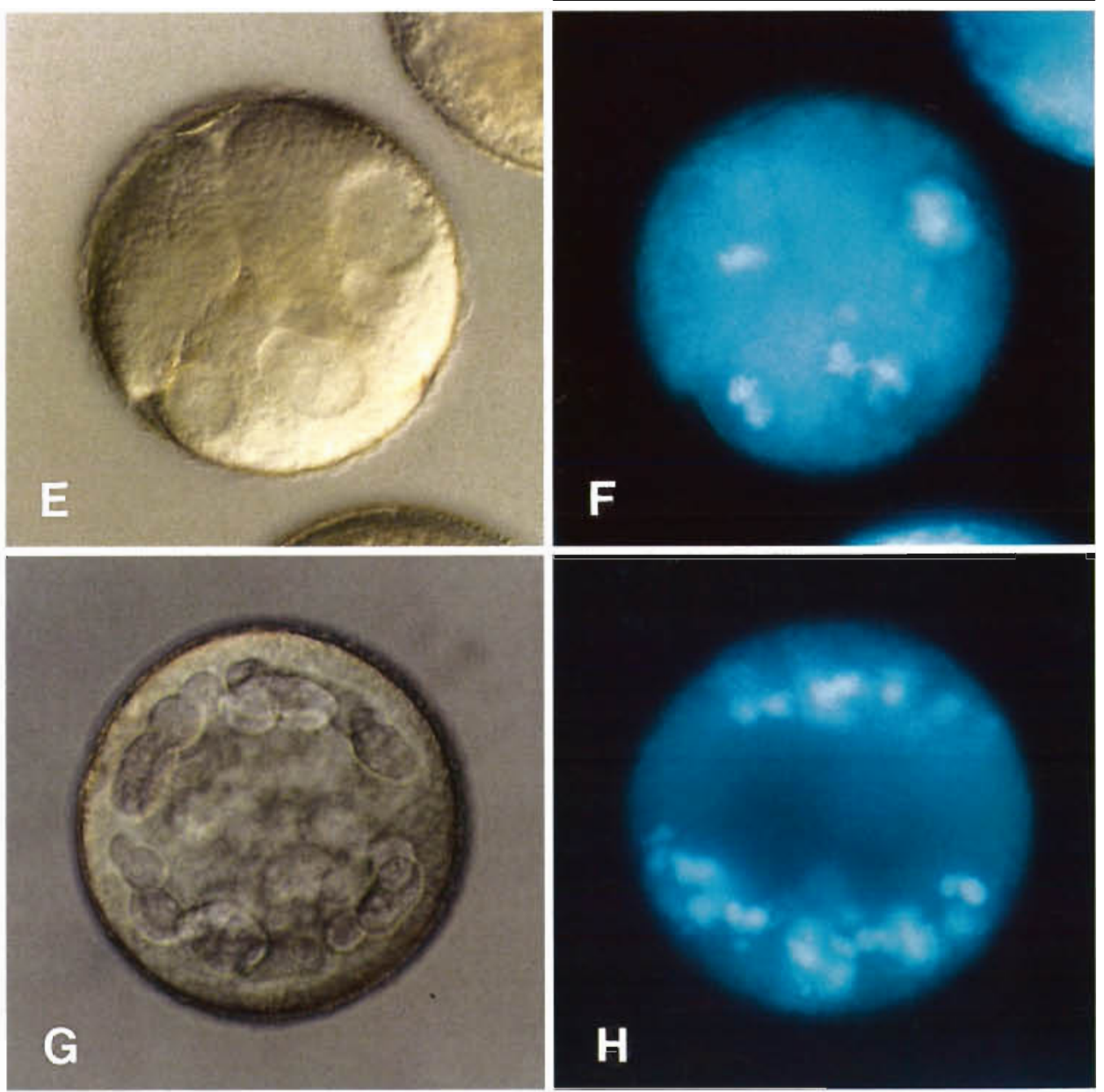

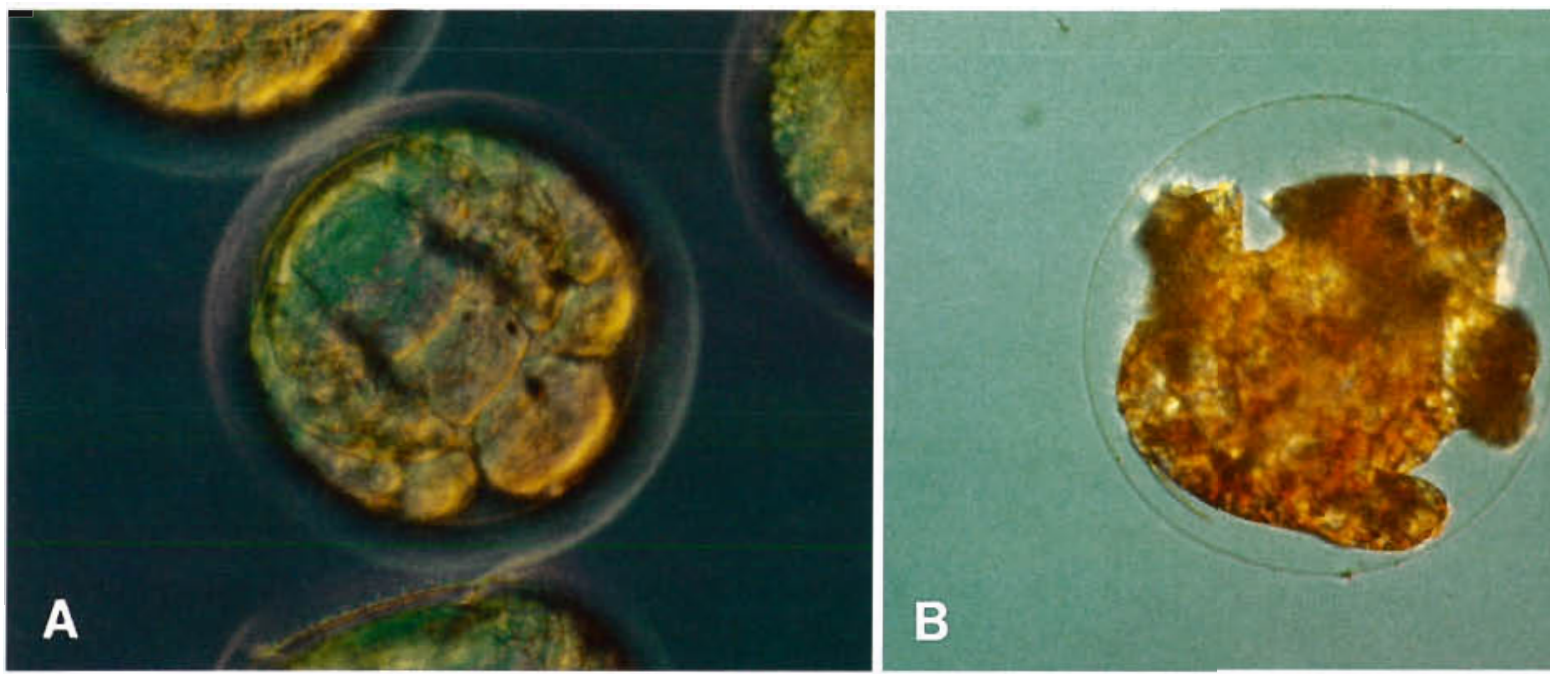

B
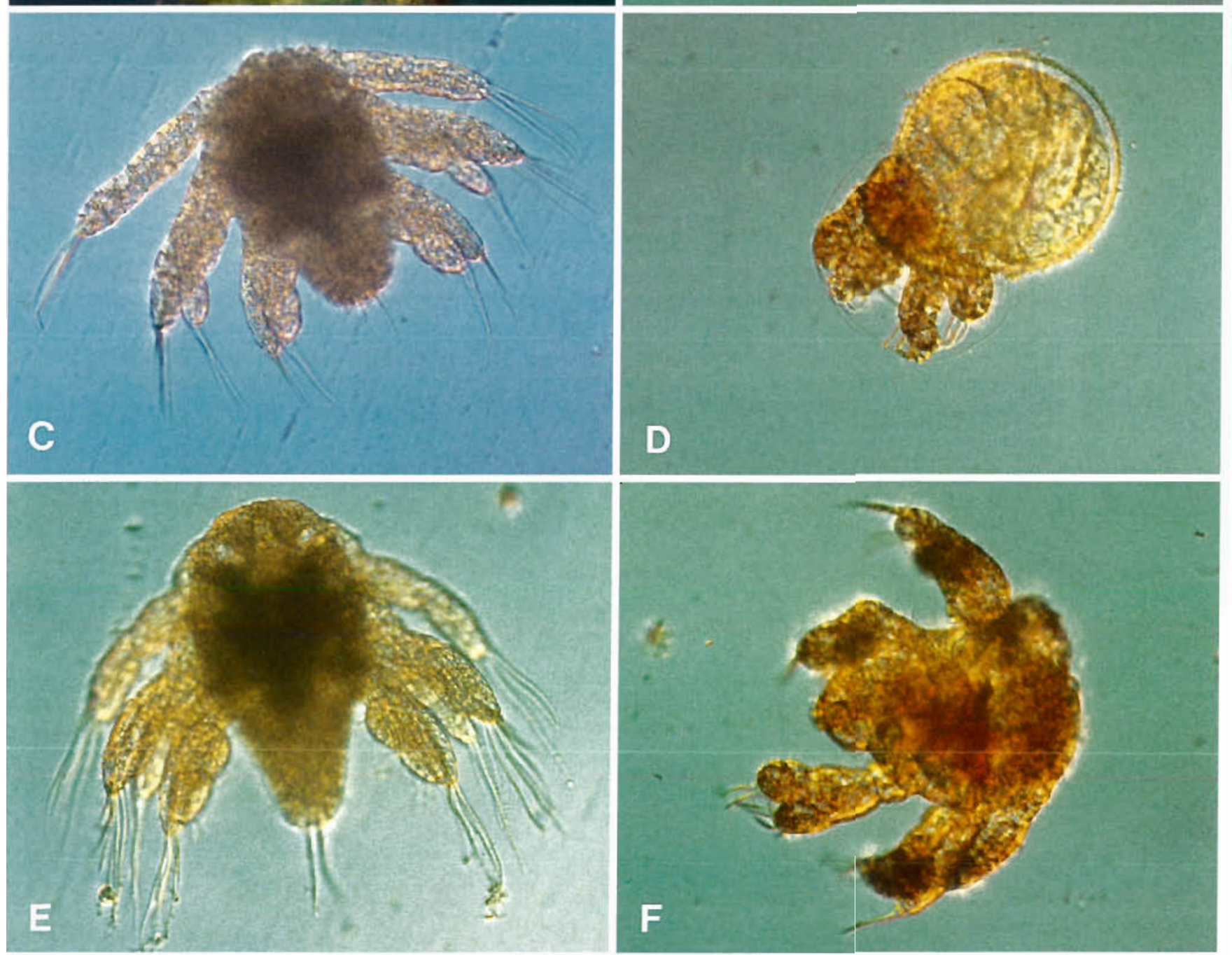

Fig 4 Calanus helgolandicus. Light mucroscope ımages of late embryos and nauphar stages in bright field Nomarsky. Left column normal embryos and naupiu (A) late embryo $20 \mathrm{~min}$ before hatching, (C) nauplius stage N1; (E) nauplius stage N2. Right column abnormal embryos and nauplu. (B) late deformed embryo trapped in egg shell, (D) partially hatched, abnormal nauplius at the N1 stage. $(F)$ deformed nauplius at the N1 stage 

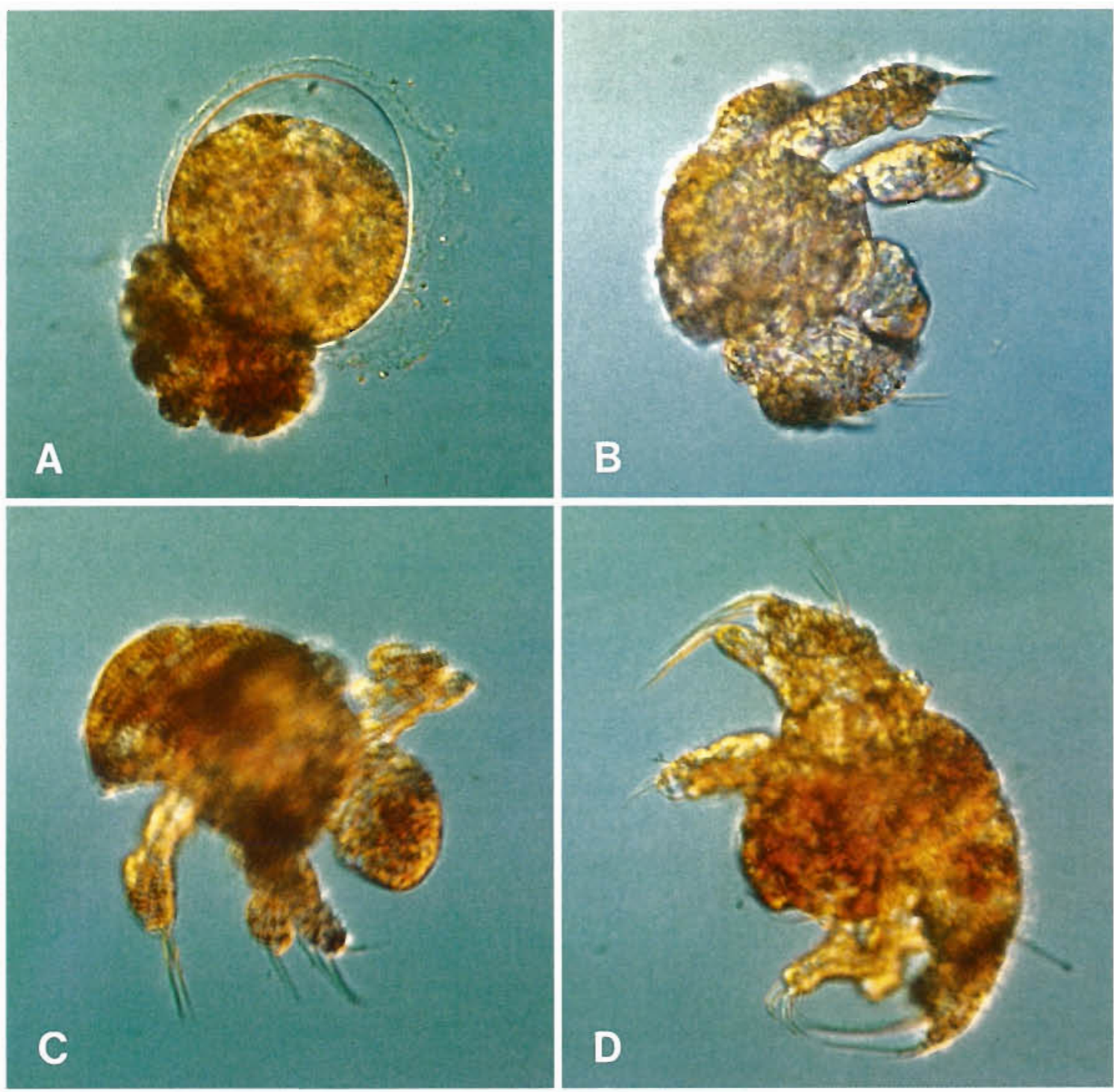

Fig. 5. Calanus helgolandicus. Light microscope images of abnormal stage N1 nauplii in bright field Nomarsky. (A) Partially hatched nauplius, and (C) dorsal view of deformed nauplius, generated by females following ingestion of Phaeodactylum tricornutum (e.g. same conditions as in Fig. 1). (B \& D) Dorsal view of hatched, deformed stage N1 nauplii, produced by wild females feeding on naturally occurring diatoms during spring-summer blooms

normal development (Fig, 4A, C, E), the body was bilateral, symmetrical, increasing in length from naupliar stages N1 to N2, more pointed posteriorly than anteriorly, with a well developed thorax and abdomen. On each side, 3 pairs of symmetrical appendages ( $\mathrm{A} 1=$ antennule, $\mathrm{A} 2$ = antenna, and $\mathrm{Md}=$ mandible) showed normal segmentation. The number, shape, length and ornamentation of bristles located at the end of both the endopodites and exopodites of these appendages were clearly visible, as shown earlier in Calanus spp. (Lebour 1916, Ogilvie 1953, Marshall \& Orr 1972). A pair of thin feelers (i.e. caudal spines) was observed at the hind end of the body.
In comparison, the main features of late abnormal embryos and N1 nauplii are illustrated in Fig. 4B, D, F. They had asymmetrical, massive bodies (Fig. 4B). In these clutches, most of the eggs did not hatch, apparently because embryos were not strong enough to break the membrane and get out of the shell (Fig. 4D). The small fraction which survived were deformed nauplii, presenting strong anatomical anomalies (Fig. 4F). The body was shortened, and strongly flexed dorsoventrally. The relative length along the anteroposterior and lateral axes of the body was modified in comparison to normal nauplii. The shape, length and segmentation of A1, A2 and Md were abnormal. The 


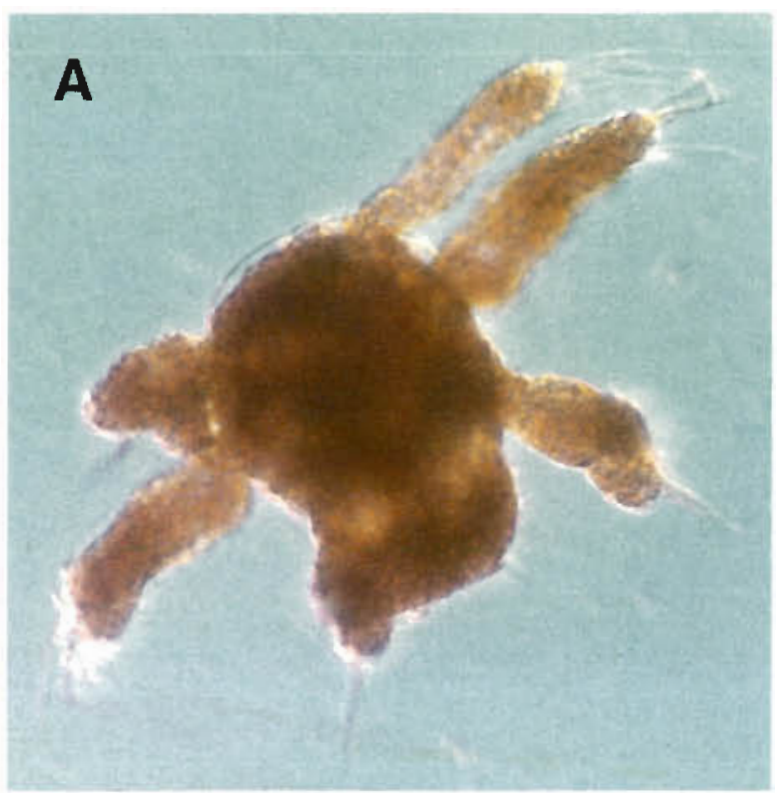

B

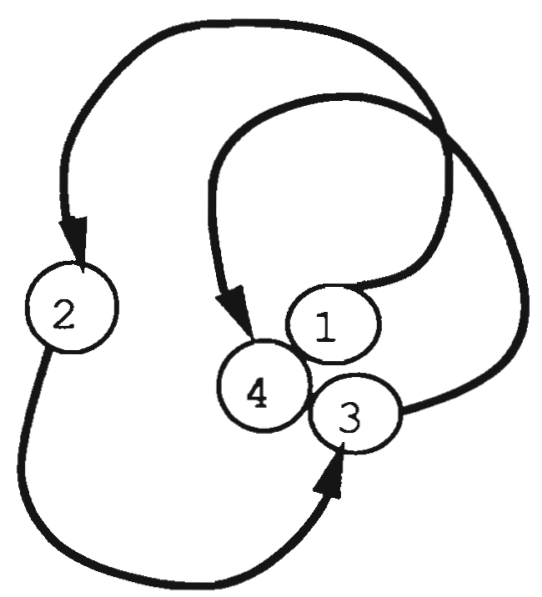

Fig. 6. Calanus helgolandicus. (A) Dorsal view of a deformed stage N1 nauplius, presenting asymmetrical left and right pairs of appendages. (B) Abnormal trajectory of the same nauplius. Displacement of a nauplius is normally linear

number and length of the bristles were reduced, and the thin feelers were not visible at the end of the body (Fig. 4F).

Other cases of abnormal nauplii are shown in Fig. 5. These types of deformities were artificially induced following ingestion of diatoms by females in the laboratory. Similar deformities have been observed in nauplii produced by wild females which had been feeding on naturally occurring diatoms (i.e. $<10^{3}$ cells $\mathrm{ml}^{-1}$; see Laabir et al. 1995a).

In most cases, abnormal nauplii were found dead at the bottom of the dishes a few hours after hatching. Although weak, some could swim, but swimming behavior was aberrant in comparison to normal nauplii. The change in swimming pattern was due to the decrease of the frequency and strength of the flicking movements of the A1, A2 and Md. Furthermore, because of the asymmetrical length of the left and right pairs of appendages (Fig. 6A), the speed and direction of the trajectory was strongly modified. For example, the physical force exerted on the water by the right, longer appendages of the nauplius, shown in Fig. 6A, was stronger than that exerted by the left ones, which were shorter and weaker. Consequently, the resulting displacement of this nauplius was not linear, as in the normal case, but twisted towards the left (Fig. 6B). Following a few flicks and pauses, this nauplius had moved, in about $10 \mathrm{~s}$, from position 1 to 4 , according to the loops sketched in Fig. 6B.

TEM studies of abnormal embryos confirmed that mitotic anomalies occurring during embryogenesis were related to erroneous cell division, corresponding to desynchronisation between nuclear division and cytokinesis (Fig. 7A). Such abnormal embryos lacked cell membrane between daughter cells (Fig. 7B). In contrast, this membrane was visible in normal embryos (Fig. 7C).

The results of image analyses of 6 biometric and 1 optical egg characteristics did not reveal any specific or significant relationship between the viability of eggs and their physical properties, as indicated by the nonsignificant value of the coefficient of correlation computed for each data set shown in Fig. $8(0.33<r<0.57$; $\mathrm{p}>0.05$ ). This technique, applied to 3 to $5 \mathrm{~h}$ old embryos, was therefore useless in predicting hatching success in a given sample of eggs.

\section{DISCUSSION}

Inhibition by diatoms of embryonic development in copepods was recently demonstrated (Poulet et al. 1994, Ianora et al. 1995). Complementary and new results are presented in Figs. 2, $3 \& 4$, which illustrate the morphological succession of anomalies during abnormal embryogenesis in Calanus helgolandicus. Hatching success decreased (Fig. 1) as a consequence of 2 major cellular anomalies during mitosis: the mismatch between the timing of the nuclear division and cytokinesis, and the absence of a cell membrane between daughter cells (Figs. $3 \mathrm{C}-\mathrm{H}$ \& 7). The link between ingestion of diatoms by females and the following abnormal mitoses detectable during embryogenesis of the offspring has never been reported before.

Reports on deformities in nauplii (Fig. 4D, F; Fig. 5) are also new. In the laboratory as well as in the field, observations revealed that these deformities also re- 

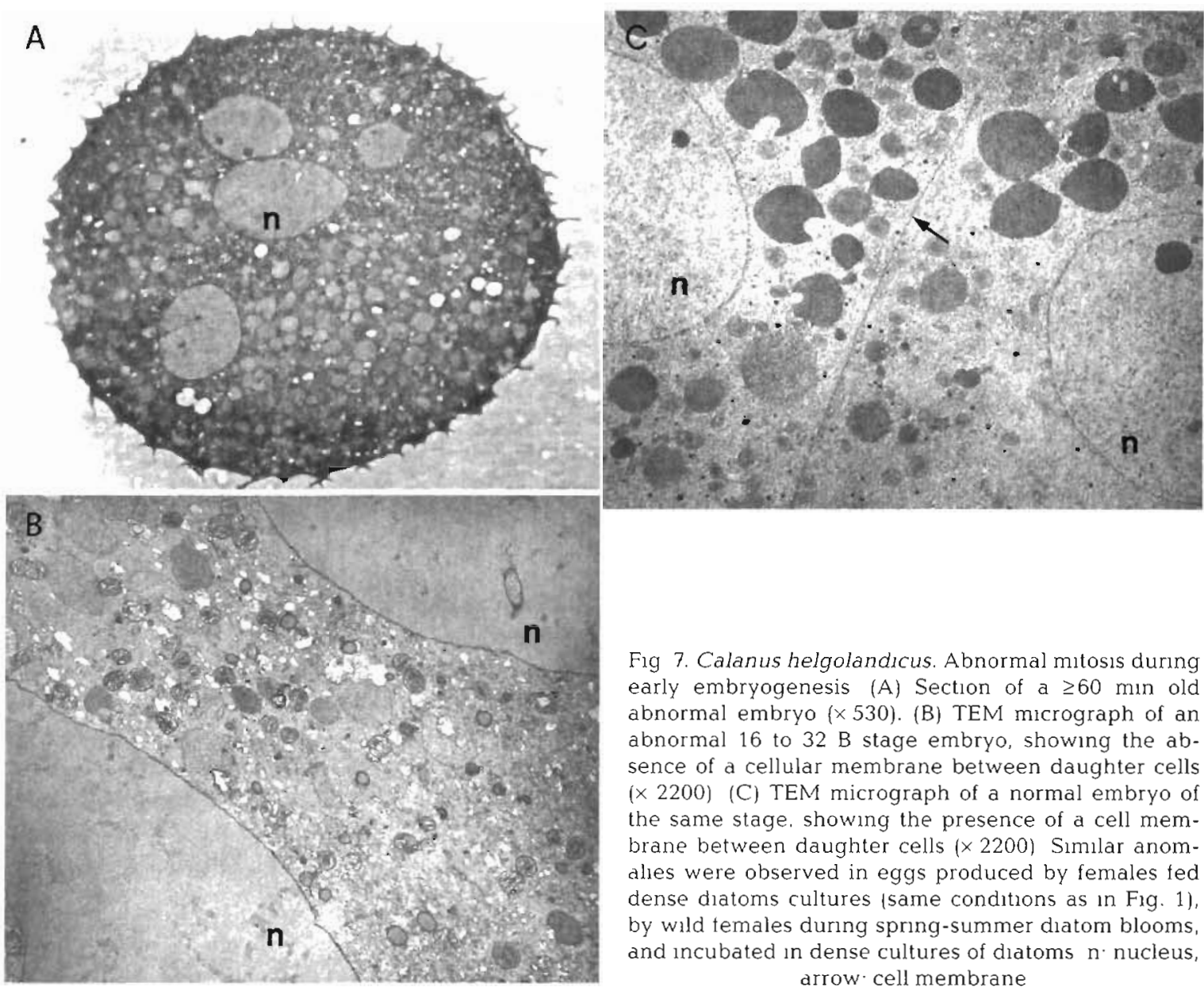

Fig 7. Calanus helgolandıcus. Abnormal mitosis during early embryogenesis (A) Section of a $\geq 60 \mathrm{~min}$ old abnormal embryo $(\times 530)$. (B) TEM micrograph of an abnormal 16 to $32 \mathrm{~B}$ stage embryo, showing the absence of a cellular membrane between daughter cells ( $\times 2200)$ (C) TEM micrograph of a normal embryo of the same stage. showing the presence of a cell membrane between daughter cells $(\times 2200)$ Similar anomalies were observed in eggs produced by females fed dense diatoms cultures (same conditions as in Fig. 1), by wild temales during spring-summer dıatom blooms, and incubated in dense cultures of diatoms n- nucleus, arrow cell membrane
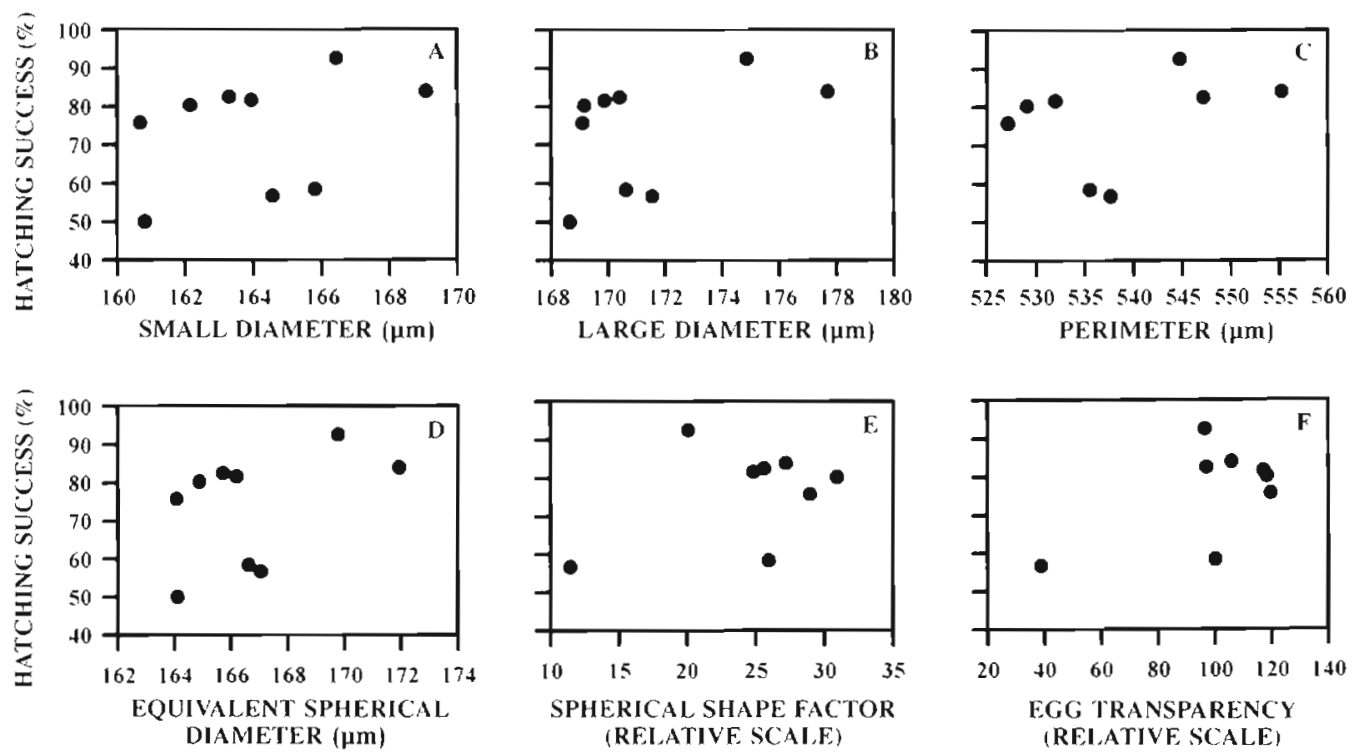

Fig. 8. Calanus helgolandicus. Results of image analyses of embryos ( 3 to 5 h old) Plots of hatching success versus 6 physical characteristics of the embryos observed microscopically. (A) small drameter, (B) large diameter, (C) perimeter, (D) equivalent spherical diameter, (E) spherical shape factor, $(F)$ egg transparency Each data set corresponds to the monthly mean values of clutches of $n=50$ to 180 eggs, spawned in the laboratory by wild females 


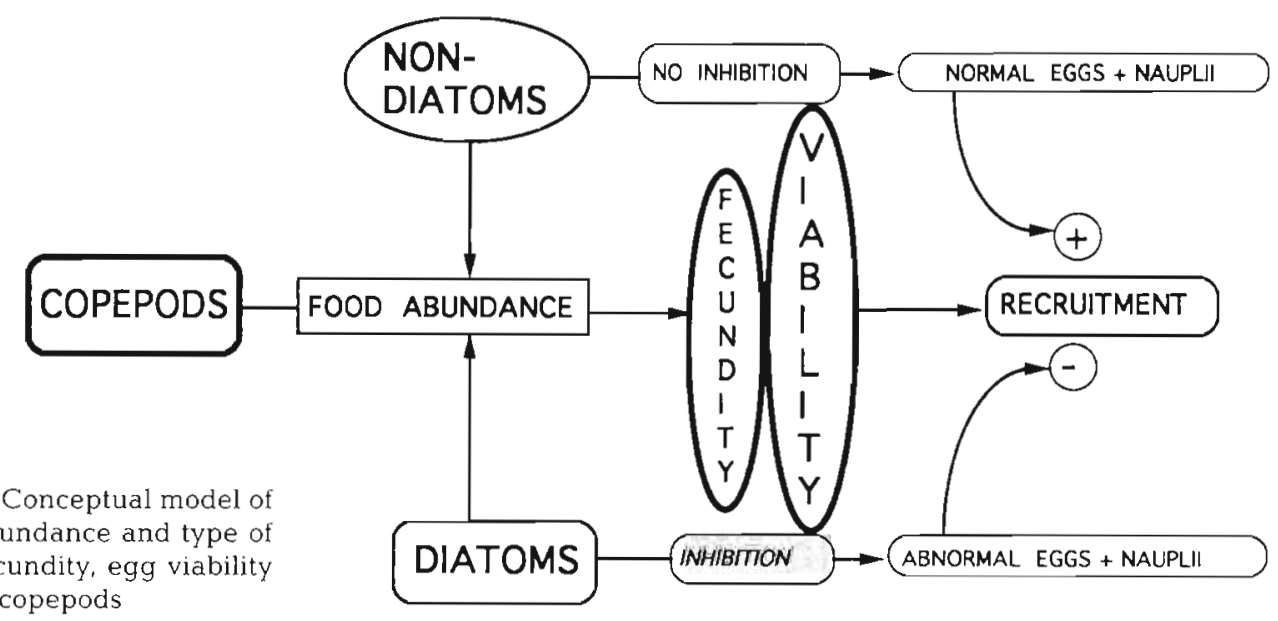

Fig. 9. Calanus helgolandicus. Conceptual model of functional responses to the abundance and type of food ingested, determining fecundity, egg viability and recruitment of copepods

To summarize, copepods are subject to highest morsulted, in both cases, from ingestion of diatoms by females (Fig. 1; Laabir et al. 1995a). At this stage, the relation between cause and effect of diatoms inhibiting embryonic and naupliar development of Calanus helgolandicus was shown for the first time at the cellular level.

The question is: what is the ecological implication of this mechanism in copepod population dynamics? This inhibitory process seems to be triggered by the quantity of diatoms ingested by females (Laabir et al. 1995a): the more diatoms ingested, the more antimitotic agents accumulated in oocytes during vitellogenesis, and the lower the hatching success. At a given concentration, inhibition may also be influenced by the duration of feeding on diatoms (Fig. 1; Laabir et al. 1995a). It is obvious that feeding selectivity on diatoms would enhance this mechanism. On the contrary, it is believed that diversity of diets (i.e. omnivory) and shifts from diatom to non-diatom diets may relax inhibition. This hypothesis has been verified both in the laboratory and in the field for Calanus helgolandicus (Laabir et al. 1995a). The functional model in Fig. 9 shows that fecundity is controlled primarily by food abundance, whatever the type of algal diet, following a well-established relationship in copepods (Runge 1984, Hirche et al, 1991, Plourde \& Runge 1993). However, a fraction of this production is not viable. One of the major causes of unsuccessful hatching is believed to be related to antimitotic agents existing in diatoms (Fig. 1) as also shown in other copepod species (Ianora \& Poulet 1993, Miralto et al. 1995). According to this model, production of abnormal eggs and weak, deformed nauplii (Figs. 5 \& 6) should reduce recruitment as a consequence of their low viability and of the increased susceptibility of these deformed nauplii to predation, probably due to their reduced ability to escape predators (Fig. 6). tality during their early phases of life, even though the relative proportions of mortality due to predation and to other causes are still not well identified in nature (e.g. Landry 1975, 1978, Mullin 1988, Liang et al. 1994, Peterson \& Kimmerer 1994). Field estimates of 'natural mortality' of embryos in Calanus helgolandicus (Laabir et al. 1995a) and Centropages typicus (Ianora et al. 1992) vary seasonally between 20 and $100 \%$ of the total daily egg production. Peterson \& Kimmerer (1994) reported that only $10 \%$ of the eggs produced by Temora longicornis survived to first nauplius. The present observations, in addition to previous reports (Landry 1975, Mullin 1988, Liang et al. 1994, Peterson \& Kimmerer 1994), show that viability of copepods is not very high during the egg-naupliar stages. This characteristic should be incorporated into population dynamic studies.

Acknowledgements. We thank Mr G. Gragnaniello for assistance in the TEM preparations. We also thank Dr R. Williams for examining the manuscript.

\section{LJTERATURE CITED}

Arnaud J, Brunet M, Mazza J (1978) Studies on the midgut of Centropages typicus (Copepoda, Calanoida). I. Structural and ultrastructural data. Cell Tissue Res 187:333-353

Hirche HJ, Baumann $M$, Kattner $G$, Gradinger $R$ (1991) Plankton distribution and the impact of copepod grazing on primary production in Fram Strait, Greenland Sea. J mar Syst 2:477-494

Ianora A, Mazzocchi MG, Grottoli R (1992) Seasonal fluctuations in fecundity and hatching success in the planktonic copepod Centropages typicus. J Plankton Res 14: $1483-1494$

Ianora A, Poulet SA (1993) Egg viabiluty in the copepod Temora stylifera. Limnol Oceanogr 38:1615-1626

lanora A, Poulet SA, Miralto A (1995) Inhibition of copepod 
egg viability by diatoms. Mar Biol 121:533-539

Jonasdottir SH (1994) Effects of food quality on the reproductive success of Acartia tonsa and Acartia hudsonica: laboratory observations. Mar Biol 121:67-81

Kasahara S, Uye S, Onbe T (1975) Calanoid copepod eggs in sea-bottom muds. Il. Seasonal cycles of abundance in the populations of several species of copepods and their eggs in the inland Sea of Japan. Mar Biol 31:25-29

Kiorboe T, Nielsen TG (1994) Regulation of zooplankton biomass and reproduction in a temperate, coastal ecosystem. 1. Copepods. Limnol Oceanogr 39:493-507

Kjorsvik E, Mangor-Jensen A, Holmefjord l (1990) Egg quality in fishes. Adv mar Biol 26:71-113

Laabir M, Poulet SA, Ianora A (1995b) Measuring production and viability of eggs in Calanus helgolandicus. J Plankton Res 5:1125-1142

Laabir M, Poulet SA, lanora A, Miralto A, Cueff A (1995b) Reproductive response of Calanus helgolandicus. II. In situ inhibition of embryonic development. Mar Ecol Prog Ser 129:97-105

Landry MR (1975) Seasonal temperature effects and predicting development rates of marine copepod eggs. Limnol Oceanogr 20:434-440

Landry MR (1978) Population dynamics and production of a planktonic marine copepod, Acartia clausi, in a small temperate lagoon on San Juan Island, Washington. Int Revue ges Hydrobiol 63:77-119

Lebour MV (1916) Stages in the life history of Calanus finmarchicus (Gunnerus), experimentally reared by Mr. L. R. Crawshay in the Plymouth Laboratory. J mar biol Ass UK 11:1-17

Liang D, Uye SI, Onbe T (1994) Production and loss of eggs in the calanoid copepod Centropages abdominalis Sato in Fukuyama Harbor, the inland Sea of Japan. Bull Plankton Soc Japan 41:131-142

Lopez MDG, Huntley ME, Lovette JT (1993) Calanoides acutus in Gerlache strait, Antarctica. 1. Distribution of late copepodite stages and reproduction during spring. Mar Ecol Prog Ser 100:153-165

Marshall SM, Orr AP (1972) The biology of a marine copepod.

This artucle was submitted to the editor
Springer-Verlag, Berlin

Miralto A Ianora A, Poulet SA (1995) Food type induces different reproduction responses in the copepod Centropages typıcus. J Plankton Res 7:1521-1534

Mullin MM (1988) Production and distribution of nauplii and recruitment variability. Putting the pleces together In: Toward a theory on biological-physical interactions in the world ocean. Kluwer Academic Publishers, Dordrecht, p $297-320$

Ogilvie HS (1953) Copepod nauplii (I). ICES, Zooplankton $50: 1-3$

Peterson WT, Kimmerer WJ (1994) Processes controlling recruitment of the marine calanoid copepod Temora longicornis in Long Island Sound: egg production, egg mortality, and cohort survival rates. Limnol Oceanogr 39: $1594-1605$

Plourde S, Runge JA (1993) Reproduction of the planktonic copepod Calanus finmarchicus in the lower St. Lawrence estuary - relation to the cycle of phytoplankton production and evidence for a Calanus pump. Mar Ecol Prog Ser 102:217-227

Poulet SA, Ianora A, Laabir M, Klein Breteler WCM (1995) Towards the measurement of secondary production and recruitment in copepods. ICES J mar Sci 52:359-368

Poulet SA, Lanora A, Miralto A, Meijer A (1994) Do diatoms arrest embryonic development in copepods? Mar Ecol Prog Ser 111:79-86

Reynolds ES (1963) The use of lead citrate at high $\mathrm{pH}$ as electron-opaque stain in electron-microscopy. J Cell Biol 17:208-212

Runge JA (1984) Egg production of the marine, planktonic copepod Calanus pacificus Brodsky: laboratory observations. J exp mar Biol Ecol 74:53-66

Uye S (1982) Population dynamics and production of Acartia clausi Giesbrecht (Copepoda; Calanoida) in inlet waters. J exp mar Biol Ecol 57:55-83

Williams R, Wallace MA (1975) Continuous plankton records: a plankton atlas of the North Atlantic and North Sea: supplement 1 -- the genus Clausocalanus (Crustacea: Copepoda, Calanoida) in 1965. Bull mar Ecol 8:167-184

Manuscript first received: January 2, 1995

Revised version accepted: May 16, 1995 